\title{
8 Cosmic Evolution and Evil
}

\author{
CHRISTOPHER SOUTHGATE
}

\section{INTRODUCTION TO COSMIC THEODICY}

This chapter will concern itself with what the sciences tell us about the structure and unfolding of the cosmos and the implications of those accounts of natural processes for the problem of evil. I shall be writing as a Christian theologian about the problems evil poses for a Christian understanding of the loving character of God, confessed as the creator and redeemer of the world.

I shall take the term 'evil' in its technical sense in this debate, as connoting the suffering of sentient beings (both human and nonhuman), and the infliction of such suffering by conscious, freely choosing agents. So wicked actions constitute only a proportion of what may be regarded as evil in this broader sense. Indeed, the most difficult areas of the problem of evil for the Christian theologian concern that suffering which cannot be attributed to the action of freely choosing agents and must therefore be attributed in some sense to the activity of God as creator.

Theodicy is the general term for efforts to reconcile the loving character of God with evils in the world. For the purposes of this chapter I shall refer to theodicy in respect of suffering caused by the natural processes of the universe as 'cosmic theodicy'. This will include suffering caused to human beings by natural disasters and by disease, be it inherited or caused by parasites or other pathogens, and also suffering caused to other sentient beings by predation, competition, and disease, leading at times to actual species extinction. In focusing on evil caused by natural processes, I recognize that this is often exacerbated by human cruelty or neglect. For example, the effects of the Indian Ocean tsunami of 2004 were made worse by the lack of an early-warning system, such as already existed in the Pacific, by the destruction of mangrove swamps on the coasts, and by the civil war in Banda-Ace. Yet there remains a very 
substantial amount of evil that must be assigned to the natural processes of the world.

Currently, the most interesting area of this subject concerns arguments that suggest that the suffering of sentient creatures is somehow a necessary element in the arising of values such as we see in this world. I shall evaluate these arguments and indicate where I think theology needs to supplement them.

But before embarking on such an analysis I need to acknowledge the power of what might be called 'anti-theodicy'. Some very important thinkers have rejected any sort of calculus by which God's action in allowing evils within creation can be justified. In their different ways such scholars as Kenneth Surin, Terrence Tilley, D. Z. Phillips, and John Swinton all make eloquent cases that such calculation is at best counterproductive and at worst downright evil in itself. ${ }^{.}$For Phillips, for example, it is simply an error to write of the divine as though God were a moral agent like human moral agents. For Tilley, theorizing about evil may itself prove to be a source of evil.

For Surin and Swinton, priority must rather be given to listening to the voices of the victims of evil, to the alleviation of their suffering, and to resisting those who cause it. In my own work I have focused on the sufferings of non-human creatures, caused by other such creatures, over the many millennia for which sentient creatures capable of suffering have been victims of aspects of the evolutionary process. These victims do not have 'voices' in any ordinary sense, nor can their suffering necessarily be alleviated, nor is it straightforward to think of resisting its causes. Nevertheless, this is a huge area of creaturely suffering that constitutes a charge against the goodness of God. So there are clearly aspects of this problem that escape at least some of the critique of the anti-theodicists.

The Scriptures, which are the natural starting point for the Christian theologian seeking to discern the ways of God with the world, offer curiously little help to the philosophical theodicist. They are certainly not interested in proving either the existence of God or the logical compatibility of belief in a loving God with the existence of profound suffering. They are not afraid to protest against God, as in the long central narrative of the Book of Job, or to cry out in the sort of lament that is full of protest, as in many of the Psalms. Indeed, it might be argued

K. Surin, Theology and the Problem of Evil (Oxford: Basil Blackwell, I986); T. Tilley, The Evils of Theodicy (Georgetown, VA: Georgetown University Press, I99I); D. Z. Phillips, The Problem of Evil and the Problem of God (London: SCM Press, 2004); J. Swinton, Raging with Compassion: Pastoral Responses to the Problem of Evil (Grand Rapids, MI, and Cambridge: Eerdmans, 2007). 
(pursuing a line of thought from Terry Eagleton²) that the question 'why', which shrieks loud on the lips of sufferers and echoes long in the ears of Christian ministers after natural disasters, is not a philosophical request for a reason at all. It is rather something much more primal, a fusion of protest and lament.

Insofar as the Christian Scriptures do offer any hints as to the reason for suffering, these hints, disturbingly to the modern sensibility, suggest that suffering can be an instrument of the purposes of God. In the Old Testament, God sometimes sends suffering through the medium of what we would now see as natural processes, as punishment for sin, or as part of a divine plan. The story of the plagues of Egypt (and indeed the destruction of the Egyptian army at the Reed Sea) is the classic example. Even the New Testament is by no means free of the notion that suffering serves the purposes of God (Jn 9.I-3; I I.7-I4; Rom. 5.2-5; Col. I.24; I. Pet. 3.I7-I8). At the centre of the Christian confession is the conviction, never explained though endlessly theorized over, that 'the Son of Man must suffer... and be killed' (Mk 8.3 I $)^{3}$ and that on that death rests the salvation of the world. So Jesus' innocent suffering, which came to be seen as the redemptive suffering of the divine Son, is understood to be instrumental in the purposes of God. I return to this point later.

The question raised by these initial reflections is: What should a Christian theodicist attempt? Some philosophical theologians, such as Richard Swinburne and Alvin Plantinga, have sought to provide logical demonstrations of the goodness of God in the face of evil, demonstrations that would convince someone of no faith. ${ }^{4}$ Michael J. Murray has sought to consider what arguments might qualify as such demonstrations in respect of 'nature red in tooth and claw'.5 I am not convinced that such arguments are very generative. It is not my experience that those whose preconceptions run counter to the compatibility of suffering and divine love are convinced by philosophical analyses. Rather, I prefer to think of theodicy as an exploration, from within the confessing community, of the ways of God with the world, given a belief in divine sovereignty and divine love. I make no distinction here between 'theodicies' and 'defences', since I am not convinced that these terms are clearly distinguished in the literature.

\footnotetext{
T. Eagleton, On Evil (New Haven, CT: Yale University Press, 20Io). All biblical quotations are from the New Revised Standard Version. R. Swinburne, Providence and the Problem of Evil (Oxford: Oxford University Press, I998); A. Plantinga, God, Freedom and Evil (Grand Rapids, MI: Eerdmans, 1974).

M. J. Murray, Nature Red in Tooth and Claw: Theism and the Problem of Animal Suffering (Oxford: Oxford University Press, 2008).
} 
In 2007, Andrew Robinson and I published an analysis of different types of 'good-harm analysis' (GHA). ${ }^{6}$ We pointed out that all attempts at rational theodicy tend to involve an aspect of balancing harms to creatures against goods that might arise in connection with those harms. This balancing will tend to be of one of three kinds.

Property-consequence GHAs: a consequence of the existence of a good, as a property of a particular being or system, is the possibility that possession of this good leads to it causing harms.

Developmental GHAs: the good is a goal that can only develop through a process which includes the possibility (or necessity) of harm.

Constitutive GHAs: The existence of a good is inherently, constitutively inseparable from the experience of harm or suffering.

A familiar example of the first kind would be the free-will defence to moral evil. God is taken, in this defence, to have endowed humans with the property of freedom, the consequence of which is that humans often commit evil. Developmental arguments may be most pertinent to cosmic theodicy; it could for example be held that God instituted the process of evolution because it would give rise to certain goals, although harms were likely, or indeed certain, to arise. Constitutive arguments are the most subtle and elusive. One way to read the ever-problematic story of the sacrifice of Isaac in Gen. 22 would be that only in the crisis of Mount Moriah, sacrificial knife in his hand at God's command, does Abraham come to know the true character of the divine love.

\section{THREE PROPOSALS IN COSMIC THEODICY}

I now proceed to consider three moves in cosmic theodicy by important thinkers at the interface of science and theology. All three argue in different ways for a 'package deal' understanding, for a necessary connection between positive values arising within creation, such as beauty, creaturely ingenuity and diversity, and negatives or disvalues, in particular suffering and extinction. Robert J. Russell has been at pains to insist that the basic structure of the physical universe as God has created it, in particular the Second Law of Thermodynamics, is a source

\footnotetext{
C. Southgate and A. Robinson, "Varieties of Theodicy: An Exploration of Responses to the Problem of Evil based on a Typology of Good-Harm Analyses." In Physics and Cosmology: Scientific Perspectives on the Problem of Evil. Ed. N. Murphy, R. J. Russell, and W. R. Stoeger SJ (Vatican City and Berkeley, CA: Vatican Observatory and Center for Theology and the Natural Sciences, 2007), 67-90.
} 
both of creaturely possibilities and of creaturely suffering.7 (Put at its simplest, the Second Law states that the overall degree of disorder in a physical system will always tend to increase. This is the underlying reason why biological organisms, in general, continually need to take on nutrients and why they ultimately decay.) The nature of thermodynamics makes possible increases in complexity in the biological world, but it also makes inevitable decay and death and the life-strategies that follow from that.

John Polkinghorne has advanced what he has called the 'free-process' defence - 'all of created nature is allowed to be itself according to its kind, just as human beings are allowed to be according to their kind' ${ }^{8}{ }^{8}$ At first sight this might be supposed to be a property-consequence argument by analogy with the free-will defence. The version of the argument recently offered (in other terms) by Elizabeth Johnson would indeed be of this form. It is a good - in her terms - that physical processes have their own autonomy and cause the cosmos to unfold according to their freedom. Perhaps surprisingly given her neo-Thomist framework, she wants to insist that these free processes are not instruments of the divine purpose. ${ }^{9}$ But if this is the case, then it is not clear that this freedom is a good, certainly not a good that could be weighed against the harms that natural processes cause (for example through earthquakes, volcanoes, etc.).

Rather, the free-process defence is most helpfully seen as developmental - the freedom of physical processes is a good because it gives rise to the evolutionary development of certain values on Earth, values that, it may be presumed, God desired. So the tectonic processes that give rise to earthquakes have had an essential role in distributing and recycling nutrients to allow this to become and continue to be a planet fruitful for life. The asteroid impact that led to the extinction of the dinosaurs made possible the rise of the mammals and with that the possibility of intelligent life, culminating in modern human beings.

Holmes Rolston III has made a number of telling contributions to the debate. Particularly important are, first, his exposition of why disvalues in nature are closely bound up with values and why predation is necessary for complex life, ${ }^{\text {Io }}$ and second, his rejection of the notion that the

7 R. J. Russell, "Natural Theodicy in an Evolutionary Context: The Need for an Eschatology of New Creation." In Cosmology: from Alpha to Omega by R. J. Russell (Minneapolis, MN: Fortress Press, 2008), 249-72.

8 J. Polkinghorne, Exploring Reality: The Intertwining of Science and Religion (London: SPCK, 2005), I43.

9 E. Johnson, Ask the Beasts: Darwin and the God of Love (London: Bloomsbury, 2014).

Io H. Rolston, III, "Disvalues in Nature," The Monist 75 (I992): 250-78. 
natural world stands in need of redemption. For Rolston, the processes by which the matter of a dead creature is recycled through other organisms does itself constitute redemption. ${ }^{\text {II }}$ I return to the subject of redemption in what follows.

We are now beginning to have a sense of what has become a central issue in the contemporary debate in cosmic theodicy. Aspects of the natural processes of the world are profoundly ambiguous - they necessarily generate harms, be it the 230,000 human beings killed by the tectonic movement that caused the Indian Ocean tsunami or the myriad creatures torn apart by predators over the millennia of evolutionary history. At the same time they also generate values, a world fruitful for life, and a process (natural selection) that refines the characteristics of creatures, leading to the biosphere we know today. A number of scholars writing in this area want to suggest that certain types of natural law and process, be it the Second Law, plate tectonics, or natural selection, are necessary for the development of these values, in other words that God could not have created this sort of world without this extent of suffering. This was, even for God, the only way in which to give rise to the values we see in this world. Aside from Russell, Polkinghorne, and Rolston, others who have written along these lines include Robin Attfield, Nancey Murphy, and myself. ${ }^{12}$ The notion of a package deal - the values cannot be had without the disvalues - is explicitly articulated by Niels Gregersen and Denis Alexander. ${ }^{13}$

II H. Rolston, III, "Does Evolution need to be Redeemed?" Zygon 26 (I994): 205-29.

I2 R. Attfield, Creation, Evolution and Meaning (Aldershot: Ashgate, 2006); N. Murphy, "Science and the Problem of Evil: Suffering as a By-Product of a FinelyTuned Cosmos." In Physics and Cosmology: Scientific Perspectives on the Problem of Evil. Ed. N. Murphy, R. J. Russell, and W. R. Stoeger SJ (Vatican City and Berkeley, CA: Vatican Observatory and Center for Theology and the Natural Sciences), I 3 I-5 I; C. Southgate, The Groaning of Creation: God, Evolution and the Problem of Evil (Louisville, KY: Westminster John Knox Press, 2008), ch. 3. Two articles criticizing the 'the only-way' argument have appeared since this chapter was drafted. They are N. W. O'Halloran SJ, "Cosmic Alienation and the Origin of Evil: Rejecting the 'Only Way' Option," Theology and Science, I3:I (2015): 43-63; and M. Wahlberg, "Was Evolution the Only Possible Way for God to Make Autonomous Creatures? Examination of an Argument in Evolutionary Theodicy," Int. J. Philos. Relig. 77 (2015): 37-5 I. O'Halloran's advocacy of a primordial spiritual rebellion, 'a higher organizing principle of disorder and evil within the cosmos', is vulnerable to the same concerns indicated later in my chapter in respect of Lloyd's work. However, Wahlberg's article is very helpful in requiring 'only-way' theorists to clarify exactly what it was that God could not know or do that made evolution a necessary means of creating creaturely selves.

I3 N. H. Gregersen, "The Cross of Christ in an Evolutionary World," Dialog: A Journal of Theology, 40.3 (2001): 192-207; D. Alexander, Creation or Evolution - Do We Have to Choose? (Oxford: Monarch, 2008). 
Two questions then arise. First, what is this constraint on the power of God? Why was it not possible for God to create in some other, less suffering-filled way? Second, is this assertion - that this was the only or the best way that God could give rise to a world containing beauty, ingenuity, and diversity - sufficient to constitute a theodicy? I return to these questions after considering how what I am calling cosmic theodicy would have been tackled in the tradition.

\section{TRADITIONAL THEODICIES BASED ON A FALL-EVENT}

An enormous weight of Christian thought has rested on the notion that disvalues in the world, be they the toil of human life or the struggle of other creatures, are the product of the first human sin, as described in Genesis 3. This is still the reflex response of most Christians, and it is an urgent task for theological education to convey the inadequacy of this answer. The answer is problematic biblically, because even within the Genesis narrative itself the curse of Chapter 3 seems to be repented of at the end of Chapter $8 .{ }^{\mathrm{I} 4}$ And there is very little sign in the rest of the Hebrew Bible of the notion of a primordially corrupted world. ${ }^{\text {Is }}$ (Rather, the processes of the world, including predation, are affirmed in such important passages on the theology of creation as Ps. IO4 and Job 38-4I.) The notion of a 'cosmic fall' is also deeply problematic in the light of the scientific record. There is not the slightest evidence that humans ever lived harmoniously with all other creatures in a vegetarian paradise as depicted in Genesis 2. Moreover, predation and disease preceded human life by hundreds of millions of years.

The only refuge from these arguments from science is either to suppose that Eden was a special zone, insulated from the rest of the world, or that some sort of time reversal occurred. The first strategy can be found in Stephen Webb's The Dome of Eden and the second in William Dembski's The End of Christianity. ${ }^{16}$ Webb's picture does not seem altogether consistent as to the extent of evil powers corrupting the creation and arrives at a fanciful picture for which there is no textual evidence. Dembski contrives a very elaborate argument about time but arrives at a

${ }_{14}$ The work of Bethany Sollereder (Ph.D. thesis, University of Exeter, 20I4) brings this out particularly clearly.

I5 J. Bimson, "Reconsidering a "Cosmic Fall,'" Science and Christian Belief I8 (2006): 63-8I.

I6 S. Webb, The Dome of Eden: A New Solution to the Problem of Creation and Evolution (Eugene, OR: Wipf and Stock, 20I0); W. A. Dembski, The End of Christianity: Finding a Good God in an Evil World (Nashville, TN: Broadman and Holman, 2009). 
position that is no theodicy at all. His God imposes suffering on myriad creatures because humans will one day sin.

Some scholars who accept the inadequacy of assigning disvalues in the creation to human sin nevertheless want to distance God from the violence and suffering of creation. Michael Lloyd is an example of a scholar who defends an angelic fall as the cause of suffering in creation. ${ }^{17}$ This view is deeply difficult theologically, not only because of the lack of biblical evidence that the world is so corrupted, but also because it assigns to spiritual entities opposed to God more power than Christian theology has been willing to concede. God's sovereignty is severely compromised in schemes in which God set out to create straw-eating lions and was prevented from doing so. Furthermore, it is deeply difficult for theology in conversation with science to dissect out some elements of the physical world and assign those to malefic influences while attributing all beauty, order, and creativity to God. The whole essence of the scientific picture as it has emerged since the nineteenth century is that it is the same processes - tectonics, creaturely decay, mutation, natural selection, to name only a few - that generate the suffering as also generate the beauty, ingenuity and diversity of the world of creatures.

A more sophisticated version of a 'primordial fall' is found in the work of Neil Messer. ${ }^{18}$ Messer's reading of Karl Barth encourages him to invoke a mysterious counter-force, Das Nichtige (nothingness), which prevents God from effecting the creation God desired. This formulation is subject to all the scientific and theological problems noted earlier and is in any case a contestable reading of Barth. ${ }^{19}$ But it is important to note the theological motivation behind Messer's account (and Lloyd's). These authors cannot associate the God of Jesus Christ with the creation of processes that involve, indeed that seem to depend on, violence. This shows that this problem of cosmic theodicy cannot be treated in isolation from a whole range of other theological trajectories. And it must

${ }_{17}$ M. Lloyd, "Are Animals Fallen?" In Animals on the Agenda: Questions about Animals in Theology and Ethics. Ed. A. Linzey and D. Yamamoto (London: SCM Press, I998); "The Humanity of Fallenness." In Grace and Truth in a Secular Age. Ed. T. Bradshaw (Grand Rapids, MI: Eerdmans, I998).

I8 N. Messer, "Natural Evil after Darwin." In Theology after Darwin. Ed. M. S. Northcott and R. J. Berry (Milton Keynes: Paternoster, 2009), I 39-54. This thinking is taken up in some important work on animal theology - see D. Clough, On Animals: Volume I: Systematic Theology (London: Continuum, 2012).

I9 For further analysis, see C. Southgate, "Re-reading Genesis, John and Job: A Christian's Response to Darwinism," Zygon 46.2 (20II): 365-90; "God's Creation Wild and Violent, and Our Care of Other Animals," Perspectives on Science and Christian Faith 67 (2015): 245-53. For a different theological approach, see C. Southgate, "Divine Glory in a Darwinian World," Zygon 49.4 (2014): 784-807. 
be acknowledged that Messer poses a hard question about 'only way' arguments such as the ones that I began to discuss earlier. Why must we picture God as constrained to act in a way that makes violence intrinsic to creation and necessitates a vast extent of creaturely suffering? The difficulty of that position persuades scholars such as Messer and Lloyd to seek alternatives that, as I have indicated, are themselves profoundly problematic. (A further, very problematic move currently being explored is to suppose that a whole range of other animals commit sin. ${ }^{20}$ )

Delving further into Messer's position leads one to ask whether this counter-force he postulates is a conscious agency (like Lloyd's fallen angels) or a part of the logical fabric of reality. If the former, then Messer's view seems to default to the sort of dualist position in which God cannot overcome the influence on creation of an evil counter-deity, a view that the Christian tradition has steadfastly resisted. If the latter, then his argument seems to acquire a congruence with only-way arguments in which the disvalues in creation become a necessary concomitant of the values. His 'Nichtige' argument is a theological guess at a constraint on God, drawing its strength from Barth's not-wholly-clear language, and beyond that from the old tradition that evil has no real existence but is only a privation of the good. Only-way arguments, in contrast, are scientifically informed guesses at a constraint on God, drawing their strength from the contemplation of the world as science describes it and the inference that if God could have created without these suffering-filled natural processes, God would have done so.

There are other arguments analogous to Messer's postulate of a mysterious force or factor leading to an ambiguous creation. This type of argument may be deemed an appeal to 'mysterious fallenness'. Celia Deane-Drummond, likewise reluctant to accept that God might be implicated in the creation of violent processes, writes of 'Shadow Sophia', the underside of the wisdom in creation. ${ }^{21}$ Yet it is never clarified what this influence is. Likewise, Nicola Hoggard Creegan has written of the disvalues in creation as being like the 'tares' in the parable of the wheat and the tares. However, in the parable, the tares are sown by an 'enemy' (Mt. I3.24-30), whereas Hoggard Creegan is reluctant to say what the origin of the disvalue is. ${ }^{22}$

20 Clough, Animal Theology; J. Moritz, "Animal Suffering, Evolution, and the Origins of Evil," Zygon 49.2 (2014): 348-80.

${ }_{21}$ C. Deane-Drummond, Christ and Evolution: Wonder and Wisdom (Minneapolis, MN: Fortress Press, 2009), I85-9I.

22 N. Hoggard Creegan, Animal Suffering and the Problem of Evil (New York: Oxford University Press, 2013). 
It should be clear by now that cosmic processes that lead inevitably to creaturely suffering, as well as to all sorts of values, constitute a deep problem in the theology of creation. Delicate choices need to be made, none of which is problem-free. Messer himself contrasts theologies that privilege Christian doctrine, among which he would list his own cosmic theodicy, with those that in his view privilege science over doctrine. ${ }^{23}$ While his taxonomy of interactions in the science-religion debate is useful as a rhetorical device, the interactions themselves are more complex. Scientific conclusions vary from those that are highly provisional to those (like evolution by natural selection) that are strongly supported by a range of robust data accumulated over a long period. Doctrinal positions often rest on scriptural passages that can be approached from very different strategies in biblical interpretation. For example, Messer's key passage, the account of the peaceable kingdom in Is. II, can be understood in a range of ways, some cosmic and futuristic, some political and contemporary. For an account of the interpretative issues around the classic New Testament passages on the redemption of creation and of interpreters' strategies of privileging one type of text and using it to explicate others, see Horrell and colleagues (2010).24 Also, predictions about the future (as for example regarding the ultimate fate of the universe) have a very different status in the debate from accounts of past events. There is an inherent uncertainty about the future that places it in a different category from the past or yet the present. In the case under discussion, the account of why there exist natural processes that have caused and do cause great suffering, robust science encounters theology at its most tentative, as theology must be in discussing the problem of evil. There is thus good reason for taking the main lines of the scientific conclusions with the utmost seriousness.

\section{'ONLY WAY' ARGUMENTS}

I return now to the argument we began to map at the beginning of this chapter, namely that suffering-causing natural processes are necessary to the realization of values within creation. I phrase this argument as follows: 'This was the only, or at least the best, process by which creaturely values of beauty, diversity and simplicity could arise' ${ }^{25}$

23 N. Messer, Selfish Genes and Christian Ethics: Theological and Ethical Reflections on Evolutionary Biology (London: SCM Press, 2007), 48-62.

24 D. G. Horrell, C. Hunt, and C. Southgate, Greening Paul: Re-Reading the Apostle in a Time of Ecological Crisis (Waco, TX: Baylor University Press, 2010).

25 Southgate, Groaning of Creation, 48. 
The key questions this argument raises are:

I. What is this constraint on God? and

2. Is such an argument enough of a theodicy?

First, I consider the nature of the constraint. According to usual Christian understandings of God's power, that power is only limited by logical constraint - God cannot make $2+2$ equal 5 or the ratio of diameter to circumference of a circle to be other than 3.I4I59. It is not possible, at our current level of knowledge, to show that the constraint in the only-way argument is a logical constraint. Nevertheless, it makes common sense to a scientist. It is hard to imagine a universe not governed by the Second Law of Thermodynamics. It is hard to imagine /outside the script of Star Trek) a chemistry for life fundamentally different from the one we know on earth. It is hard to imagine an evolutionary process in which natural selection is not a very significant factor. But I am grateful to Dr Mark Ian Thomas Robson for pointing out that a Lamarckian universe, based on the inheritance of behaviours acquired during an organism's lifetime, is imaginable. The question would then be, is it plausible that such a universe would actually 'work' and have a better balance of goods and harms given what would need to change to neutralize the possibilities of natural selection?

Many hypothetical universes could be constructed, but it is not demonstrable that Attfield is wrong ${ }^{26}$ and that there exists a type of universe that would give rise to a better balance of values against disvalues. It cannot be shown that this is a logical truth. The guess that God could no more dream into being a completely different sort of life-bearing universe than a square circle cannot be proven, but it is a reasonable hunch that it might be so. As we have seen, the theological alternatives to onlyway arguments are not attractive. But only-way arguments leave the Christian theodicist in an uncomfortable position, having to assert that God, in the divine desire to create, was constrained to create processes to which suffering was intrinsic in pursuit of ends to which suffering was instrumental. I indicated in my opening comments on Scripture that instrumental suffering is not as foreign to the Christian imagination as some thinkers would like it to be. But it cannot be the end of the story, any more than Calvary was the end of Christ's story.

It seems to me that as Christians puzzle out the ways of God with the world, those who want to defend an orthodox faith that insists on the unity of creation and redemption must suppose not one but two

26 Attfield, Creation, Evolution and Meaning, ch. 6. 
constraints on God. The first is the one I introduced earlier, that God creates under some not-wholly-comprehensible constraint, such that a world evolving by natural selection, and therefore necessarily involving the suffering of sentient creatures, is the only sort of world in which the values represented by complex and diverse life could arise. The second constraint on God, amply familiar from Christian teaching, though still not clearly or univocally understood, is the necessity, oft-repeated in the New Testament, that Jesus should have to endure degrading execution to release, finally and fully, the redemptive purposes of God into the world.

The first of these constraints is unfamiliar to most Christians. The second is routinely confessed in various ways throughout the Church. But I would submit that they are comparable mysteries - indeed, if anything, the first is easier to understand than the second, since the first has the intuitions of the natural sciences to commend it, whereas the intuitions of a culture based on a sacrificial system are remote from us. Both carry that difficult sense that suffering might be instrumental to the divine purpose that I noted earlier.

To contemplate God in relation to the natural world is to contemplate both immense, staggering, unimaginable power and at the same time a powerlessness we cannot quite fathom either - the creation we so delight in and wonder at cannot arise all at once but only by an immensely long birthing, full, in Paul's word in Romans 8.20, of 'futility'. And the redemption of the world cannot be magicked either but only arises out of the sacrifice of the divine Son.

Having set the only-way argument in more of a philosophical and theological context, it remains to consider our second question: Is it enough to point to such a constraint in order to reconcile the loving character of God with the nature of this suffering-filled world? The difficulty with a theodicy that simply asserts that this is the best sort of system God could have created is that such theodicy describes a God who is the creator of systems but not a God who is in loving relationship with creatures. It is my view, therefore, that the best contemporary cosmic theodicies must start from a version of the only-way argument, but they must go on to make other moves that are more focused on God's relationship with the individual creature.

\section{THE ROLE OF DIVINE REDEMPTION IN COSMIC THEODICY}

Russell has made a careful analysis of the options in what we are calling cosmic theodicy and concludes that none of them is satisfactory without 
a redemptive dimension. ${ }^{27}$ We noted already that Rolston offers such a dimension in supposing that the cycles of nutrition constitute redemption of the dead creature. The impala calf torn apart by hyenas is for Rolston redeemed by the nourishment they and the bacteria in their guts extract from its corpse. But this, once again, is an argument at the level of the system and not the individual creature.

How then is the impala calf to experience the meaning of God's love? Only via a redemption beyond this present world, a redemption in the form of some sort of new life in the final 'new creation' at the eschaton. To include an eschatological dimension to cosmic theodicy is, as Russell shows, a necessary complement to only-way type arguments. If the love of God is shown in the re-creation of lives - at least those that have not known fullness of life - then the challenge to that love from suffering seems to retreat, and it once again becomes possible to stress God's love for the individual creature. ${ }^{28}$

However, the challenge returns in a different form. Because the possibility of such a new creation, in which (in the traditional visions we are offered in passages such as Is. I I; Rev. 2I.I-4) there is no more pain, begs the question - why did God not just create in this way in the first instance? This is where a theodicy that is considering the suffering of all sentient creatures and not just mentally competent self-conscious humans must reject a straightforward appeal to 'Irenaean' argument, to the initial creation as a school in which individual creatures learn virtue. ${ }^{29}$ So much of the suffering that concerns the cosmic theodicist is of creatures who are not in a position to learn from the experience, because they are physically torn apart or their lives are otherwise destroyed (e.g. by cataclysm, chronic disease, torture, or profound abuse).

The logic of the only-way argument is that particular sorts of values, embodied in creaturely selves, could only arise (or could best arise) through the operation of natural processes such as we see in this world. The challenge of the question, why did God not just create heaven? - posed for example by Wildman ${ }^{30}$ - necessitates an extension of the argument, as follows:

27 Russell, "Natural theodicy."

${ }_{28}$ A particular concern in D. Edwards, "Every Sparrow that Falls to the Ground: The Cost of Evolution and the Christ-Event," Ecotheology I I.I (2006): I03-23.

29 J. Hick, Evil and the God of Love (London: Palgrave Macmillan, 2010 [I970]).

30 W. J. Wildman, "Incongruous Goodness, Perilous Beauty, Disconcerting Truth: Ultimate Reality and Suffering in Nature." In Physics and Cosmology: Scientific Perspectives on the Problem of Evil in Nature. Ed. N. Murphy, R. J. Russell, and W. G. Stoeger, SJ (Vatican City and Berkeley, CA: Vatican Observatory and Center for Theology and the Natural Sciences, 2007), 267-94. 
embodied $^{3 \mathrm{I}}$ creaturely selves, which can only arise within an evolving world, are capable, once they have so arisen, of being transformed to a state in which they flourish without the possibility of suffering, but they cannot arise except within a world constrained by natural processes such as thermodynamics and natural selection.

Again, this can only be a guess, but it is the guess that fits best the scientific and theological constraints within which cosmic theodicy must operate.

Further questions arise about the nature and scope of the redeemed life of creatures. Will it be simply an 'objective immortality' in which all that is of value from individual lives is held within the loving memory of God, or will there be subjective experience? In I987, Rolston introduced the example of the 'insurance' pelican chick, the second chick hatched by the white pelican, which is normally pushed out of the nest and starves. It is only 'needed' when the older chick fails to thrive. Rolston's comment that if God watches over the insurance chick, he does so from a vast distance, was rejected by Jay McDaniel, who propounded the notion of 'pelican heaven' as an expression of a subjective, redeemed experience for such victims of evolution. ${ }^{32}$ Indeed, subjective immortality for creatures seems more in keeping with Christian visions of the eschaton. It is also more in keeping with the logic of Johnson's notion of 'deep resurrection'. ${ }^{33}$ But it is extremely difficult to gain much traction in speculations as to whether only 'victims' or every sentient creature or indeed every creature receives redeemed life (or indeed how predators will be themselves in such a life). ${ }^{34}$

\section{THE PROBLEM OF PROVIDENCE}

A dimension of the problem of cosmic theodicy not yet touched on concerns God's providential action. Christian theologies picture God as immanently and lovingly present to all created entities and usually as acting selectively, providentially, in the physical world and the lives of certain creatures to bring about divine purposes. There is a very

${ }^{3}$ I As opposed to forms of spiritual being, such as angels.

$3^{2}$ H. Rolston, III, Science and Religion: A Critical Survey (Philadelphia and London: Templeton Foundation Press, 2006 [I987]); J. B. McDaniel, Of God and Pelicans: A Theology of Reverence for Life (Louisville, KY: Westminster John Knox Press, I989).

33 This takes up Gregersen's notion of 'deep incarnation', which he introduced in "The Cross of Christ"; on deep resurrection, see Johnson, Ask the Beasts, 208-Io.

34 For a set of speculations, see Southgate, Groaning of Creation, ch. 5. 
extensive literature on such divine action. ${ }^{35}$ What is striking is how the contemporary debate is focusing more and more on the interaction with theodicy; if God interacts with a single situation to benefit a single group of creatures, does this not place a moral responsibility on God to benefit similar creatures in other similar situations? Yet the world abounds with situations in which God seems not to have helped creatures. This question has been taken up with particular honesty by Wesley Wildman, whose conclusion is that it is wrong to regard the divine as benevolent. ${ }^{36}$ Philip Clayton and Steven Knapp have concluded that God cannot, morally, act to change some physical situations but not others (their 'not even once' principle, which they apply tellingly to the case of the 2004 tsunami). Rather, they believe that God's action can be expressed in terms of encouragement and lure towards virtue. ${ }^{37}$

It is hard to reconcile this with the providential action within the human world described in Scripture and tradition, not least God's raising of Jesus from the dead. ${ }^{38}$ But when one turns to the relationship between God and non-human creatures over the whole sweep of evolution, it may be that God's providential engagement is best understood in terms of loving, compassionate presence and lure rather than more overt intervention in the chain of physical causes. In William Rowe's famous example of the fawn suffering horribly through being trapped in a forest fire, ${ }^{39}$ it is possible to accept that God companions each suffering fawn, but not necessary (and deeply problematic) to imagine God saving one specific fawn while letting others perish in agony.

It is also reasonable to go on to suppose that the divine presence expresses God's love for creatures and therefore also that God suffers

35 K. Ward, Divine Action: Examining God's Role in an Open and Emergent Universe (West Conshohocken, PA: Templeton Foundation Press, 2007 [I990]); R. J. Russell, N. Murphy, and W. R. Stoeger, SJ (eds.), Scientific Perspective on Divine Action: Twenty Years of Challenge and Progress (Vatican City and Berkeley, CA: Vatican Observatory and the Center for Theology and the Natural Sciences, 2008); D. Edwards, How God Acts: Creation, Redemption, and Special Divine Action (Minneapolis, MN: Fortress Press, 20IO); C. Southgate, "A Test Case - Divine Action." In God, Humanity and the Cosmos: A Textbook in Science and Religion. Ed. C. Southgate (London: Bloomsbury, 3rd edn, 20II), 274-3 I 2.

36 Wildman, "Incongruous Goodness."

37 P. Clayton and S. Knapp, The Predicament of Belief: Science, Philosophy, Faith (New York: Oxford University Press, 201 I).

${ }^{8}$ Clayton and Knapp, Predicament, ch. 5.

39 W. L. Rowe, "Friendly Atheism, Skeptical Theism, and the Problem of Evil," Int. J. Philos. Relig. 59 (2006): 79-92. Rowe's critique of theodicies is taken up in N. Trakakis, The God beyond Belief: In Defence of William Rowe's Evidential Argument from Evil (Dordrecht: Springer, 2007). 
with the suffering of creatures that suffer. Since we have no idea what the inner experience of other creatures feels like to them, we can have no idea how the compassionate presence of God might make a difference. But it is a reasonable theological instinct that it does make a difference $^{40}$ and that no creature in this sense dies alone. It is also a reasonable instinct, though much contested, that this suffering makes a difference to God and that God suffers 'in, with and under'4r the suffering of creatures. ${ }^{42}$ This commitment of God to creatures' pain finds its epitome in the Passion of Christ, which in recent thinking must be seen as identification not only with human suffering but with all creatures. ${ }^{43}$

This sense of the role of the Cross and the Atonement may lead to a refinement of the only-way argument. I have given reasons to suppose that God was constrained in how to create a universe if it was to be fruitful for life, for intelligent life, for the extraordinary range and beauty of life as we know it. But it may be that an additional constraint existed, that the cosmos must be such as to give rise to a life form that could incarnate the life of God, as Christians believe that Jesus did, and inaugurate the era of redemption that will culminate in a state in which 'there will be no more crying' for 'God will be all in all' (Rev. 2 I.4; I. Cor. I 5.28).

To understand the full possibilities of such a cosmic theodicy, it is important to clarify the shape of the narrative that is being proposed. Scholars who insist of the necessity of a fall event sometimes argue as follows: for the Cross of Jesus to be required to transform the world, which originally was created 'very good' (Gen. I.3I), that world must have been subject to corruption. Fiddes refers to this as a 'U-shaped' narrative and points out that this is not the only possible narrative shape. ${ }^{4}$ Rather, what an evolutionary view has to propose is that the world is not so much corrupted as intrinsically (and necessarily) limited, unable to transcend itself until the Incarnation, Passion, and Resurrection of the divine Son make that self-transcendence possible. A further step in the

40 Southgate, "Does God's Care Make Any Difference? Theological Reflection on the Suffering of God's Creatures." In Christian Faith and the Earth: Current Paths and Emerging Horizons in Ecotheology. Ed. E. M. Conradie, S. Bergmann, C. DeaneDrummond, and D. Edwards (London: Bloomsbury, 20I4), 97-I I4.

${ }_{4 I}$ A. Peacocke, "Kenotic Creation and Divine Action." In The Work of Love: Creation as Kenosis. Ed. J. Polkinghorne (London, Grand Rapids, MI, and Cambridge: SPCK and Eerdmans, 200I), 2 I-42.

42 For the debate about whether God can suffer, such a significant element in contemporary theodicy, see P. Fiddes, Participating in God: A Pastoral Doctrine of the Trinity (London: Darton, Longman and Todd, 2000).

43 Gregersen, "The Cross of Christ."

44 P. Fiddes, Freedom and Limit: A Dialogue between Literature and Christian Doctrine (Macon, GA: Mercer University Press, I999), ch. 3. 
argument is the one at which Paul the Apostle hints in that extraordinary passage about the cosmos, Rom. 8.r9-22. Paul claims there that the whole creation awaits 'the freedom of the glory of the children of God' (8.2 I). This gives support to a narrative in which the final transformation of the cosmos awaits the free loving human response to the initiative of God in Christ. Only then will the world see that eschatological state from which pain and struggle has been eliminated. ${ }^{45}$

The further question of how this narrative of creation and salvation would interact with that of another planetary biosphere, if there were intelligent life elsewhere in the universe, is one that is attracting increasing attention from theologians. ${ }^{46}$ It would certainly bear on the issue of cosmic theodicy in the following ways. First, it would shed light on whether indeed life could form out of a significantly different chemistry and whether less suffering would transpire in such a world. All I have said earlier sheds some doubt on the former possibility and major doubt on the latter. Second, it would lead to challenging questions for Christian theologians about the potential intersection of two narratives of salvation. Is it the work of Jesus of Nazareth that heals the whole cosmos, or would each civilization have its own incarnation?

\section{CONCLUSION}

This chapter has focused on the suffering that arises from the natural processes of the world. I have shown that Christian theology needs to part company with explanations of such suffering based on a fall event and have explored instead the very difficult territory of accepting that these were the only types of processes by which God could give rise to the values we see in this world. I suggested further that this theodicy at the level of systems must be complemented by an emphasis on eschatological redemption of creatures and on God's compassionate relating to them in their suffering.

\section{FURTHER READING}

Clayton, Philip and Steven Knapp. The Predicament of Belief; Science, Philosophy, Faith. New York: Oxford University Press, 20 I I.

45 On this eschatological state, see J. Polkinghorne, The God of Hope and the End of the World (London: SPCK, 2002).

46 E.g. D. Wilkinson, Science, Religion and the Search for Extra-Terrestrial Intelligence (Oxford: Oxford University Press, 2013). 
Drees, William B. (ed.). Is Nature Ever Evil? London: Routledge, 2003 (especially article by Rolston).

Murphy, Nancey, Robert John Russell, and William R. Stoeger, SJ (eds.). Physics and Cosmology: Scientific Perspectives on the Problem of Evil. Vatican City and Berkeley, CA: Vatican Observatory and Center for Theology and the Natural Sciences, 2007.

Murray, Michael J. Nature Red in Tooth and Claw: Theism and the Problem of Animal Suffering. Oxford: Oxford University Press, 2008.

Russell, Robert John. "Natural Theodicy in an Evolutionary Context: The Need for an Eschatology of New Creation." In Cosmology: from Alpha to Omega by Robert John Russell. Minneapolis, MN: Fortress Press, 2008, 249-72.

Southgate, Christopher. The Groaning of Creation: God, Evolution and the Problem of Evil. Louisville, KY: Westminster John Knox Press, 2008.

Surin, Kenneth. Theology and the Problem of Evil. Oxford: Basil Blackwell, I 986. 